\title{
Promising Plant Sources of Anti-Diabetic Micronutrients
}

\author{
Sharafetdinov Kh Kh*, Kiseleva TL, Kochetkova AA and Mazo VK
}

Federal Research Centre of Nutrition, Biotechnology and Food Safety, Moscow, Russia

*Corresponding author: Sharafetdinov Kh Kh, Federal Research Centre of Nutrition, Biotechnology and Food Safety, Moscow, Russia, Tel: +74997943516; E-mail: sharafandr@mail.ru

Received date: November 29, 2017; Accepted date: December 13, 2017; Published date: December 20, 2017

Copyright: (C) 2017 Sharafetdinov Kh Kh, et al. This is an open-access article distributed under the terms of the Creative Commons Attribution License, which permits unrestricted use, distribution, and reproduction in any medium, provided the original author and source are credited.

\begin{abstract}
Specialized foods (SF) with a predetermined chemical composition play an important role in the prevention of the most common nutrition-related diseases, including type 2 diabetes. Prospective sources of phytonutrients for the development of SF with antidiabetic action are among the priority areas of research in the field of diabetology and dietology. The methodology of search of promising plant sources of phytonutrients for SF included an analysis of the frequency of occurrence of edible and medicinal plants as part of multicomponent antidiabetic formulations traditionally used to treat DM in Russia, Belarus and Ukraine. To realize this goal. more than 200 publications have been analyzed. Of these, only 66 bibliographic sources contained multicomponent antidiabetic prescriptions in the form of collections from dried medicinal plant raw materials and multicomponent juices from fresh medicinal and edible plants. In total in the identified 66 publications, we found 550 multi-component formulations. It is shown that the leader plants are Bilberry - Vaccinium myrtillus L., Common beans-Phaseolus nanus L., Phaseolus vulgaris (L.) Savi var. nana Ach. and Great nettle-Urtica Dioica L. The results of this study can serve as the basis for the development of SF with a predetermined chemical composition using edible and medicinal plants.
\end{abstract}

Keywords: Food ingredients; Type 2 diabetes mellitus; Specialized food products; Traditional anti-diabetic recipes; Medicinal plants; Bilberry; Common bean; Great nettle

\section{Introduction}

Modern foods should not only satisfy the organism's physiological demand for nutrient materials and calories, but also serve preventive and therapeutic purposes of recovery and normalization of metabolic processes in the organism [1,2]. Phytonutrients (micronutrients produced by plants) are considered as important components of the organism's nutriome which ensure optimal performance of all its systems at the required level of its adaptive potential [3,4]. Natural sources of such phytonutrients include traditional edible and medicinal plants [3,5] which contain biologically active substances that have apparent physiological (sometimes specific) effect upon the organism [2,5-9].

Specialized foods (SF) with a predetermined chemical composition play the most important role in the preventive treatment of the most common nutrition-related diseases and are predominately used in the nutrition of patients $[1,2,5]$. The urgent task for food industry specialists, pharmacognosists and nutritionists is to find promising sources of phytonutrients for development of special foods (with significant biological activity and good application properties) for patients with type 2 diabetes mellitus (DM).

The objective of this informational and analytical study is to discover promising plant sources of phytonutrients for development of anti-diabetic special foods with the use of ethno botanical and ethno medical approaches.

\section{Materials and Methods}

In the course of the study, the following methods were applied: informational and analytical study, historical study, content analysis and categorization, grouping, rating, comparative and structural analyzes.

The methods applied in the search for promising sources of phytonutrients for special foods included an analysis of ethno botanical and ethno medical literature for frequency of mention of edible and medicinal plants used as components of multi-component anti-diabetic formulations traditionally applied for diabetes mellitus treatment in Russia and neighboring European countries (Belarus and Ukraine) followed by identification of the plants that are used most often.

We proceeded from the assumption that the index of frequency of mention in conventional formulation reference books in per cent of the total number of the analyzed publications can serve as an indirect proof of both the popularity in indigenous (traditional) medicine and the effectiveness of a specific plant for prevention and treatment of diabetes mellitus. In our experience, such an assumption can be considered accurate provided that an informational and analytical study is performed on at least 50 formulation references comprising at least 500 traditional formulations $[5,10]$.

The study was performed on available literature published between 1959 and 2014 in Russia, Belarus, and Ukraine, including reference books, monographs, and collections of traditional and indigenous medicine formulas. The total number of the analyzed publications on the study subject exceeded 200. From those, only 66 publications contained multi-component anti-diabetic formulations in the form of species made of dried medicinal plants and multi-component saps made of fresh medicinal and edible plants. In the selected 66 formulation reference books [6,11-75], we have identified 550 multicomponent formulations. 
We have previously published the results of an analysis of the frequency of mention of plants of hypoglycaemic action in traditional and indigenous medicine formulation reference books [76]. It was determined that the most common plants were bilberry- Vaccinium Myrtillus L. (bilberry leaves are mentioned in $86.4 \%$, and shoots are mentioned in $19.7 \%$ of the references), common bean - Phaseolus Nanus L., Phaseolus Vulgaris (L.) Savi var. nana Ach. (bean silique valves are mentioned in $72.7 \%$, and dried siliques are mentioned in $27.3 \%$ of the references), and great nettle - Urtica Dioica L. (leaves are mentioned in $74.2 \%$, and grass is mentioned in $12.1 \%$ of the references).

This informational study is aimed at the analysis of the frequency of mention of medicinal and edible plants in traditional anti-diabetic formulations. The number of ingredients contained in multicomponent formulations was calculated to be within the range from 2 to 12 (single-component formulations were excluded from the study). In total in the 550 anti-diabetic formulations studied (from all 66 publications analyzed), we have identified 230 names of edible and medicinal plant substances from 154 plants (from some plants, several morphological components were used, such as flowers, grass, leaves, roots). Closely related species of plants were considered as one plant, provided that the quality of the substance produced from them is currently regulated under the same reference document (a Pharmacopoeia Article, a State Standard).

Only 5 medicinal plant species, Bilberry (78.9\%), Common Bean (34.7\%), Galega Officinalis (31.8\%), Great Nettle (31.6\%), Common Dandelion (28.6\%), were identified as the most commonly used (in more than $20 \%$ of the analyzed anti-diabetic formulations in Russia, Belarus and Ukraine). Rosa canina (various botanical species) was rated the sixth with the frequency of mention of $19.1 \%$. The analysis of the frequency of mention of specific morphological components in the formulations revealed that more than $20 \%$ of the formulations include only 4 positions: bilberry leaves $(75.3 \%)$, galega grass $(31.5 \%)$, nettle leaves $(26.2 \%)$ and bean coats $(25.1 \%)$.

A summary rating of the frequency of mention of edible and medicinal plants in 66 formulation reference books of Russia, Belarus, Ukraine (in anti-diabetic formulations) [76] and in 550 traditional anti-diabetic formulations is provided in Table 1.

\begin{tabular}{|c|c|c|c|}
\hline Item No. & Plant name & $\begin{array}{l}\text { Rating of frequency of mention in } 66 \\
\text { formulation reference books }\end{array}$ & $\begin{array}{l}\text { Rating of frequency of mention in } \\
550 \text { formulations }\end{array}$ \\
\hline 1 & Bilberry - Vaccinium myrtillus, L.,Family Vacciniaceae & 1 & 1 \\
\hline 2 & $\begin{array}{l}\text { Common bean - Phaseolus nanus L. Phaseolus vulgaris (L.) } \\
\text { Savi var. nana Ach., Family Fabaceae }\end{array}$ & 2 & 2 \\
\hline 3 & Great nettle - Urtica dioica L., Family Urticaceae & 3 & 4 \\
\hline 4 & $\begin{array}{l}\text { Common dandelion - Taraxacum officinale Wigg.s.l., Family } \\
\text { Asteraceae }\end{array}$ & 4 & 5 \\
\hline 5 & $\begin{array}{l}\text { Rosa (various species) - Rosa majalis Herrn. - (Rosa } \\
\text { cinnamomea L), Family Rosaceae }\end{array}$ & 5 & 6 \\
\hline 6 & Wild strawberry - Fragaria vesca L., Family Rosaceae & 6 & 8 \\
\hline 7 & Greater burdock - Arctium lappa L., Family Asteraceae & 7 & 10 \\
\hline 8 & Peppermint - Mentha piperita L., Family Lamiaceae & 8 & 7 \\
\hline 9 & $\begin{array}{l}\text { Common chicory, wild - wild chicory (in many cases, its was } \\
\text { specifically indicated that the plant was wild-growing) - } \\
\text { Cichonum intubus L., Family Asteraceae }\end{array}$ & 9 & 12 \\
\hline 10 & $\begin{array}{l}\text { Perforate St John's-wort (common Saint John's wort) - } \\
\text { Hypericum perforatum L., imperforate St John's-wort (spotted } \\
\text { St. John's-wort) - Hypericum maculatum Crantz (H. } \\
\text { quadrangulum L.) (various species), Family Hypericaceae }\end{array}$ & 9 & 12 \\
\hline 11 & Field horsetail - Equisetum arvense L., Family Equisetaceae & 10 & 11 \\
\hline 12 & Common oat - Avena sativa L., Family Poaceae (Gramineae) & 10 & 15 \\
\hline 13 & Galega (goat's-rue) - Galega officinalis L., Family Fabaceae & 11 & 3 \\
\hline 14 & Lingonberry - Vaccinium vitis idaea L. Family Vacciniaceae & 12 & 9 \\
\hline 15 & $\begin{array}{l}\text { Common knotgrass, lowgrass - Polygonum aviculare L. Family } \\
\text { Polygonaceae }\end{array}$ & 12 & 9 \\
\hline 16 & Common flax - Linum usitatissimum L., Family Linaceae & 13 & 14 \\
\hline 17 & $\begin{array}{l}\text { Silver birch - Betula pendula Roth. (= B. alba L.), Family } \\
\text { Betulaceae }\end{array}$ & 14 & 17 \\
\hline
\end{tabular}


Citation: Sharafetdinov Kh Kh, Kiseleva TL, Kochetkova AA, Mazo VK (2017) Promising Plant Sources of Anti-Diabetic Micronutrients. J

\begin{tabular}{|c|c|c|c|}
\hline 18 & Black elder - Sambucus nigra L., Family Caprifoliaceae & 15 & 15 \\
\hline 19 & $\begin{array}{l}\text { Morus (no species specified), mulberry - Morus alba L., Family } \\
\text { Moraceae }\end{array}$ & 15 & 13 \\
\hline 20 & Elecampane - Inula helenium L., Family Asteraceae & 15 & 17 \\
\hline 21 & $\begin{array}{l}\text { Large plantain - Plantago major L., plantain lanceolinate - } \\
\text { Plantago lanceolate L. Family Plantaginaceae }\end{array}$ & 16 & 21 \\
\hline 22 & $\begin{array}{l}\text { Pharmaceutical camomile - Matricaria recutita (L.) Rauschert } \\
\text { (= M. chamo- milla L. = Chamomilla recutita (L.) Rausch.) } \\
\text { Family Asteraceae }\end{array}$ & 17 & 18 \\
\hline 23 & $\begin{array}{l}\text { Motherwort - Leonurus cardiac L. Motherwort five-bladed, } \\
\text { hairy - Leonurus quinquilobatus Gilib. (= L. villosus Desf.) } \\
\text { Family Lamiaceae }\end{array}$ & 18 & 21 \\
\hline 25 & Walnut - Jugans regia L. Family Juglandaceae & 19 & 19 \\
\hline 25 & Yarrow - Achillea millefolium L. Family Asteraceae & 20 & 27 \\
\hline 26 & Bur beggar-ticks - Bidens tripartite L. Family Asteraceae & 21 & 26 \\
\hline 27 & Blackcurrant - Ribes nigrum L. Family Saxifragaceae & 21 & 22 \\
\hline 28 & $\begin{array}{l}\text { Licorice smooth (common licorice) Glycyrrhiza glabra L. (= G. } \\
\text { glabra L. var. glandu- lifera Regel. = G. glandulifera Waldst. et } \\
\text { Kit.) Family Fabaceae }\end{array}$ & 21 & 24 \\
\hline 29 & Flint corn - Zea mays L. Family Poaceae (Gramineae) & 22 & 20 \\
\hline 30 & Heliotrope - Valeriana officinalis L. Family Valerianaceae & 23 & 23 \\
\hline 31 & $\begin{array}{l}\text { Yellow everlasting - Helychrisum arenarium (L.) Moench. (= } \\
\text { Gnaphalium arenarium L.) Family Asteraceae }\end{array}$ & 24 & 23 \\
\hline 32 & $\begin{array}{l}\text { Maybush - Crataegus laevigata (Poir) DC. Redhaw hawthorn- } \\
\text { Crataegus sanguinea Pall. Family Rosaceae }\end{array}$ & 24 & 16 \\
\hline 33 & $\begin{array}{l}\text { Devil's-club - Echinopanax elatum Nakai (syn. Oplopanax } \\
\text { elatum Nakai) Family Araliaceae }\end{array}$ & 24 & 76 \\
\hline 34 & $\begin{array}{l}\text { European centaury-Centaurium erythraea Rafn. (C. minus } \\
\text { Moenh. }=\text { C. umbellatum Gilib. }=\text { C. pulchellum (Sw.) Druce) } \\
\text { Family Gentianaceae }\end{array}$ & 24 & 24 \\
\hline 35 & Mouse-ear - Gnaphalium uliginosum L.s.I. Family Asteraceae & 24 & 26 \\
\hline 36 & European dewberry-Rubus caesius L. Family Rosaceae & 42 & 25 \\
\hline 37 & Pot marigold - Calendula officinalis L. Family Asteraceae & 61 & 26 \\
\hline
\end{tabular}

Table 1: Edible and medicinal plants most commonly used in traditional anti-diabetic formulations in Russia, Belarus, Ukraine (in the descending order).

As is evidenced by Table 1, the absolute leaders of the rating are: bilberry (leaves, shoots), bean (silique valves), and great nettle (leaves, grass). All three plants are sources of commonly used and high production volume medicinal herbal substances in Russia, and are therefore promising for further pharmacological and production studies. Considering the significant number of contraindications to the application of galega officinalis grass and seeds [11,77-81], as well as its placement at the $11^{\text {th }}$ position in the ranking of formulation reference books [76], it hardly seems feasible to include components of this alkaloid-bearing plant into the list of promising plant sources of essential nutrients for anti-diabetic special foods.

Starting from position 33 (Table 1) the grading of plants has no sense, because the mention frequency in reference books can differ from mention frequency in formulations (Table 1, lines 33-37). From our point of view, this can be explained by large territory of Russia, covering several climatic zones, and also by the wish of people to be treated with local plants. For example, devil's-club (Table 1, line 33) grows in the Far-East region of Russia, $9000 \mathrm{~km}$ from western borders of Russian Federation. This limits significantly the frequency of including the roots of this plant into antidiabetic formulations of western regions of Russia, and also Ukraine and Belarus (Table 1, line 33, column 4, position 76). In the same time, Calendula officinalis $\mathrm{L}$. (Table 1, line 37, column 4, position 26) is one of the most favorite medicinal and decorative plants in Russia, cultivated in almost all climatic zones except Far North. For pot marigold flowers (Flores Calendulae) we didn't find any verified data (experimental or clinical 
studies) on their hypoglycemic activity. In the same time pot marigold flowers contain carotenoids and large polyphenol complex, have antiinflammatory and regenerative activity and are included in State Register of Medicinal Remedies Approved in Russian Federation, and also are very popular among the people.

Besides the plants, most frequently used in reference books and antidiabetic formulations, stated in Table 1, other edible and medicinal plants, used in traditional antidiabetic formulations of Russia, Belarus and Ukraine, are presented in the following list alphabetically:

- Ache- Apium graveolens L. (Apiaceae),

- Aerva woolly- Aerva lanata (L.) Juss. ex Schult.( Amaranthaceae ),

- Alder- Alnus incana (L.) Moench (Betulaceae),

- American artichoke- Helianthus tuberosus L. (Asteraceae),

- Anise- Anisum vulgare Gaertn. (Apiaceae),

- Annual nettle- Urtica urens L. (Urticaceae)

- Aspen- Populus tremula L. (Salicaceae),

- Bachelor's-button- Centaurea Cyanus L. (Asteraceae),

- Baical skullcap- Scutellaria baicalensis Georgi (Lamiaceae),

- Barren myrtle- Arctostaphylos uva-ursi (L.) Spreng. (Ericaceae),

- Bay laurel- Laurus nobilis L. (Lauraceae),

- Bean trefoil- Menyanthes trifoliate L. (Menyanthaceae),

- Bedstraw- (Rubiaceae) (Gentianales)

- Beet sugar-Beta vulgaris L. (Chenopodiaceae),

- Berbine- Verbena officinalis (Verbenáceae),

- Blindweed-Capsella bursa-pastoris (L.) medik. (Brassicaceae),

- Bog whortleberry- Vaccínium uliginosum L. (Ericaceae),

- Broad-leaved clover- Trifolium pratense L. (Fabaceae),

- Brussels sprouts- Brassica oleracea var. gemmifera (Brassicaceae)

- Burdock- Xanthium strumarium L. (Asteraceae).

- Burnet saxifrage- Pimpinella saxifraga L. (Apiaceae),

- Bulb onion- Allium cepa L. (Liliaceae),

- Calamus root- Acorus calamus L. (Araceae),

- Cauliflower- Brassica oleracea L. var. botrytis L. (Brassicaceae)

- Chinese magnolia vine- Schisandra chinensis Baill. (Schisandraceae),

- Cloudberry- Rubus chamaemorus L. (Rosaceae),

- Common agrimony- Agrimonia eupatoria L. (Rosaceae),

- Common balm- Melissa officinalis L. (Lamiaceae),

- Common buckwheat- Fagopyrum esculentum Moench. (Polygonaceae),

- Common cat's foot- Antennaria dioica (L.) Gaertn. (Asteraceae),

- Common comfrey- Symphytum officinale L. (Boraginaceae )

- Common heather- Calluna vulgaris (L.) (Ericaceae),

- Common hop- Humulus lupulus L. (Cannabaceae),

- Common juniper- Juniperus communis L. (Cupressaceae),

- Common madder- Rubia tinctorum L. (Rubiaceae)

- Common origanum- Origanum vulgare L. (Lamiaceae),

- Common sunflower- Helianthus annuus L. (Asteraceae),

- Common tea- Thea sinensis L., Thea sinensis var. assamica (Theaceae)

- Common thyme- Thymus vulgaris L. (Lamiaceae),

- Couch grass- Elytrigia repens (L.) Nevski (Poaceae),

- Cowslip paigle- Primula veris L. (Primulaceae),

- Creeping thyme- Thymus serpyllum L. (Lamiaceae),
- Cucumber- Cucumis sativus L. (Cucurbitaceae),

- Cultivated angelica-Archangelica officinalis Moench, Angelica ajjthhhuifkrchangelica L. (Apiales)

- Cultivated apple- Malus domestica Borkh.( Rosaceae ),

- Cultivated cabbage- Brassica oleracea L. (Brassica alboglabra, Brassica arborea, Brassica bullata) (Brassicaceae)

- Danewort- Sambucus ebulus L. (Adoxaceae, Caprifoliaceae),

- Dense Mullein- Verbascum densiflorum Bertol., Verbascum thapsiforme Schrad. (Scrophulariaceae),

- Devil's apron- Laminaria saccharina (L.) J.V.Lamour. (Phaeophyceae, Laminariaceae),

- Dock- Rumex acetosa L. (Polygonaceae),

- English primrose- Primula veris L. (Primulaceae)

- European ash- Fraxinus excelsior L. (Oleaceae),

- European dogwood- Viburnum opulus L. (Caprifoliaceae)

- Fennel- Foeniculum vulgare Mill. (Apiaceae),

- Fenugreek- Trigonella foenum-graecum L.( Fabaceae ),

- Field-ash- Sorbus aucuparia L. (Rosaceae),

- Field violet- Viola arvensis Murray (Violaceae),

- French spin- Atriplex hortensis L. typ. cons. (Amaranthaceae)

- French willow- Chamerion angustifolium L. (Onagraceae).

- Garden carrot- Daucus sativus (Hoffm.) Roehl. (Apiaceae)

- Garden sage- Salvia officinalis L. (Lamiaceae),

- Garlic- Allium sativum L. (Liliaceae),

- Grape vine- Vitis vinifera L. (Vitaceae),

- Grapefruit- Citrus paradisi Macfad.( Rutaceae),

- Greater celandine- Chelidonium majus L. (Papaveraceae),

- Greek valerian polemonium- Polemonium caeruleum L. (Polemoniaceae),

- Heartsease- Viola tricolor L. (Violaceae),

- Hemp eupatorium- Eupatorium cannabinum L. (Asteraceae),

- Herb bennet- Geum urbanum L. (Rosaceae)

- Herb of grace- Ruta graveolens L. (Rutaceae),

- Iceland moss- Cetraria islandica(L.) Ach. (Parmeliaceae)

- Indian kidney tea- Orthosiphon stamineus Benth.( Lamiaceae),

- Kolomikta-vine- Actinidia kolomicta (Maxim. \& Rupr.) Maxim. (Actinidiaceae),

- King's-clover- Melilotus officinalis L. Pall. (Fabaceae (Leguminosae))

- Lady's mantle- Alchemilla vulgaris L. (Rosaceae),

- Leather bergenia- Bergenia crassifolia (L.) Fritsch (synonums: B. cordifolia (Haw.) Sternb., B. crassifoia var. cordifolia (Haw.) Boriss, Saxifraga cordifolia Haw.) (Saxifragaceae),

- Leechwort- Lespedezae hedysaroides (Pall.) Kitag. (Fabaceae),

- Lemon- Citrus limon (L.) Osbeck (Rutaceae),

- Lettuce- Lactuca sativa L. . (Asteraceae ),

- Lily-of-the-valley- Convallaria majalis L. (Liliaceae),

- Manchurian aralia- Aralia mandshurica Rupr. et Maxim., Aralia elata (Miq.) Seem. (Araliaceae),

- Medicinal lungwort- Pulmonaria officinalis L. (Boraginaceae)

- Mistletoe- Viscum album L. (Loranthaceae),

- Mug-wet- Asperula graveolens Bieb. ex Schult. et Schult. f. (Rubiaceae),

- Mustard- Brassica juncea L. (Brassicaceae)

- Myrtle-Myrtus communis L. (Myrtaceae), 
- Nutwood- Corylus avellana (L.) H.Karst. (Betulaceae),

- Old-maid's-pink- Saponaria officinalis L. (Caryophyllaceae),

- Omum plant- Carum carvi L. (Apiaceae),

- Paul's-betony- Veronica officinalis L. (Scrophulariaceae),

- Parsley- Petroselinum crispum (Mill.) Fuss (Apiaceae),

- Persian berry- Rhamnus frangula L. (Rhamnaceae)

- Pipe tree- Siringa vulgaris L. (Oleaceae),

- Potato vine- Solanum tuberosum L., (Solanaceae).

- Pumpkin- Cucurbita pepo L. (Cucurbitaceae),

- Quince tree- Cydonia oblonga Mill. (Rosaceae),

- Rattlebox- Rhinanthus crista-galli L. (Orobanchaceae),

- Red beet- Beta vulgaris L. (Chenopodiaceae),

- Sand sedge- Carex arenaria L. (Cyperaceae)

- Sea-buckthorn- Hippophaë rhamnoides L. (Elaeagnaceae ),

- Serpent grass- Polygonum bistorta L. (Polygonaceae)

- Shelf fungus- Inonotus obliquus (Ach. ex Pers.) Pil. (Hymenochaetaceae, Polyparaceae)

- Sickle alfalfa- Medicago falcata L. (Fabaceae),

- Small-leaved lime- Tilia cordata Mill. (Tiliaceae)

- Snakeflower- Lamium album L. (Lamiaceae)

- Sparrowgrass- Asparagus officinalis L., (Asparagaceae),

- Spinach- Spinacia oleracea L. (Amaranthaceae),

- Spiny eleuterococus- Eleutherococcus senticosus (Rupr. \& Maxim.) Maxim. (Araliaceae),

- Spiny restharrow- Ononis spinosa L. (Fabaceae),

- Stone bramble- Rubus saxatilis L. (Rosaceae),

- Sulfur root- Anethum graveolens L. (Apiaceae),

- Summer-and-winter radish - Raphanus sativus L. (Brassicaceae),

- Tansy- Tanacetum vulgare L. (Asteraceae ),

- Tomato- Solanum lycopersicum L. (Solanaceae),

- Watercress- Nasturtium officinale (L.) R. Br. (Brassicaceae),

- Water dropwort- Oenanthe aquatica (L.) Poir. (Apiaceae ),

- Wood betony- Betonica officinális L., synonym: Stachys officinalis (L.) Trevis. ex Briq. (Lamiaceae).

An evaluation of potential allergological and toxicological risks of application of herbal extracts of the 37 most promising plants of hypoglycemic action (see Table 1) allowed us to establish that extracts of bilberry leaves (Folia Myrtilli) or nettle leaves (Folia Urticae dioicae) are the most safe extracts [82].

The promising outlook of the use of bilberry leaf extracts as components of anti-diabetic special foods is supported by the results of in vivo studies of their hypoglycaemic and hypolipidemic properties. It is well-known that bilberry leaves contain tanning substances (up to $20 \%$ ), arbutin ( 1 to $2 \%$ ), hydroquinone (1\%), myrtillin (1 to $2 \%$ ), quercetine and other flavonoids, triterpene saponosides-ursolic acid and oleanolic acid, ascorbic acid (up to $250 \mathrm{mg} \%$ ). Studies on the physiological effect of bilberry leaf extracts began as early as 1920's. A review article from that period [83] indicates that the use of bilberry leaf extracts is effective for treatment of mild cases of diabetes in middle-aged and elderly patients. As bilberry leaf extract is not a substitute of insulin, it could be used as an auxiliary agent for treatment of diabetes without any adverse side effects. Both bilberry berries and leaves contain a wide range of polyphenols [84-86]. The main anthocyanins discovered in bilberry berries and leaves are delphinidins $(15.17 \%)$, cyanidins $(8.36 \%)$, petunidins $(6.64 \%)$, malvidins $(5.43 \%)$, peonidins $(1.87 \%)$.
It should be noted that bilberry leaf extracts have a wide spectrum of physiological effects. In particular, consumption of the ethyl acetate fraction of bilberry leaf extract (Vaccinium virgatum) in a dose of 20 $\mathrm{mg} / \mathrm{kg}$ of the body weight by ICR mice had antiamnesic effects, which, according to the authors of [87], supports the potential benefit of its use for neurodegenerative diseases. As is evidenced by [88], obesity caused by consumption of high-fat foods by C57BL/ 6 mice for a period of 10 weeks. Five weeks after starting consuming high-fat foods, the test group of mice was given $2 \%$ bilberry leaf extract ad libitum for the following 5 weeks. It resulted in a significant reduction in the rate of body weight gain, a reduction in the triglyceride level in the blood plasma and in the rate of lipid peroxidation in the liver. A reduction in the adipocyte size was observed, as well as inhibition of adipocyte differentiation and a significant decrease in the accumulation of lipids as a result of a decrease in the expression of adipocyte-specific transcription factors: peroxisome proliferative activity receptor and peroxilase acetyl coenzyme $\mathrm{A}$ and an increase in the expression of adiponectin mRNA. Furthermore, consumption of the extract improved insulin sensitivity. An analysis of the effect of bilberry leaf aqueous extract and its fractions containing flavonol glycoside and proanthocyanidins on the lipid metabolism in OLETF rats suffering from obesity established that inclusion of bilberry leaf extract into the semi-synthetic diet of the animals ( $2 \%$ of the diet) for 4 weeks had resulted in a reduction of the lipid and C-reactive protein levels in the blood serum and a decrease in the accumulation of liver triglycerides $[89,90]$. Consumption of the flavonol glycoside and proanthocyanidin fractions resulted in an apparent reduction of cholesterol in the blood serum. Whole bilberry leaf extract fractions caused a reduction in the accumulation of triglycerides in the liver, and this hypolipidemic effect, according to the authors of the study, could be associated with an increase in the liver lipolysis rate. Consumption of lyophilized powder made of bilberry leaves resulted in an apparent reduction of the cholesterol level in livers of Sprague-Dawley rats fed with a cholesterolsupplemented diet, and a histopathological analysis of the liver tissue confirmed that the accumulation of lipids had decreased [91].

According to the results of conducted information-analytical study, the experimental research of bilberry leaves (Table 1, position 1) and bean coats (Table 1, position 2) extracts was conducted and experimental confirmation of success of our ethnomedical search was obtained. The anti-diabetic effect of bilberry leaf aqueous extract was proven in the course of our studies conducted using genetic and streptozotocin-induced type II diabetes models [92,93]. Consumption of the extract for 4 weeks by obese Zucker Rats Crl: ZUC-Leprfa rats resulted in an improvement of the insulin-sensitive tissue response to exogenous administration of glucose and insulin, inhibition of blood sugar level increase and a reduction in the total cholesterol and LDL (low-density lipoproteins) cholesterol content [92]. Consumption of bilberry leaf extract resulted in an apparent reduction of the glucose and conjugated dienes levels in the blood serum, as well as demonstrated a tendency towards reduction of the glycated hemoglobin level in male Wistar rats when modeling carbohydrate metabolism disorders by means of a single intraperitoneal administration of streptozocin combined with peroral consumption of $10 \%$ fructose solution [93].

The similar research of bean coats extract allowed determining, that its antidiabetic effect (on used experimental model) is less pronounced in comparison with bilberry leaves extract [10]. Also, hypolipidemics and antioxidant effects of bean coats and bilberry leaves extracts were shown in the experiment on Wistar rats with streptozotocin-induced type 2 diabetes in combination with high carbohydrate diet [10]. 


\section{Conclusion}

Thus, the evaluation of traditional and indigenous medicine experience in Russia, Belarus, Ukraine we have conducted allowed us to determine the most commonly used medicinal plants of hypoglycemic action, which can be promising sources of phytonutrients for development of optimized anti-diabetic special foods for patients suffering from diabetes mellitus. The results of this study suggest that food industry specialists and nutritionists should consider the issue of developing special foods with significant biological activity and good application properties based on edible and medicinal plants traditionally applied for treatment.

This study was sponsored by the Russian Science Foundation (Grant No. 14-36-00041).

\section{References}

1. Vorobyova VM, Vorobyova IS, Kochetkova AA, Sharafetdinov HH, Zorina EE (2014) Modification of the Carbohydrate Composition of Confectionery Products for Those Suffering from Type II Diabetes Mellitus. Voprosy pitaniya 83: 66-73.

2. Tutelyan VA (2010) Medical Nutrition: Modern Approaches to Standardization of Diet Therapy. Moscow: Dynasty 304.

3. Tutelyan VA, Smirnova EA (2014) Role of Nutritional Micro-Ingredients in the Production of Modern Foods. In: Food Ingredients in the Production of Modern Foods; Edited by VA,Tutelyan, AP. Nechayev. Moscow: DeLi Plus 10-24.

4. Tutelyan VA (2009) On the Norm of Physiological Demand for Calories and Food Substances for Various Demographic Groups of the Russian Federation. Voprosy pitaniya 1: 4-15.

5. Tutelyan VA, Kiseleva TL, Kochetkova AA, Kiseleva MA (2015) Methodological Approaches to the Development of Formulations of Special Foods for Patients Suffering from Diabetes Mellitus on the Basis of the National Traditional Medicine Experience. Traditional Medicine 3: 44-51.

6. Kiseleva TL, Karpeyev AA, Smirnova YA, Amalitskiy VV, Safonov VP, et al. (2007) Medicinal Properties of Food Plants / Under the general editorship of Professor Kiseleva TL Moscow: Publishing House of the Federal Scientific Clinical and Experimental Center for Traditional Methods of Diagnostics and Treatment of the Healthcare and Social Development Agency of the Russian Federatio pp: 533.

7. Golovkin BN, Rudenskaya RN, Trofimova IA, Schroeter AI (2001) Biologically Active Substances of Plant Origin. Semikhov VF (3rdedn) Moscow: Nauka.

8. Blinkov IL (2017) Biological Foundations of Clinical Pharmacology Regulation of Adaptive Vital Reactions. Moscow: Pulse: 608.

9. Blinkov IL, Starodubov AK, Suleymanov SS, Shih YV (2004) Microelements (A Brief Clinical Encyclopedia). Khabarovsk: Publishing Center Institution of Further Training for Healthcare Workers: 210.

10. Tutelyan VA, Kiseleva TL, Kochetkova AA, Mazo VK, Bessonov VV, et al. (2016) Plant Sources of Phytonutrients for Special Foods of Anti-Diabetic Action / Edited by Member of the Russian Academy of Sciences Tutelyan VA, Professor Kiseleva TL, Professor Kochetkova AA. Moscow: BIBLIOGLOBUS pp: 422.

11. Agafonova IM (2010) The collection of leaflets on herbalism: a practical guide for doctors phytotherapeutists and healers. Moscow: Miklosh pp: 160 .

12. Blinov VA (2000) Medicinal plants in diabetes mellitus. Moscow: OAO Izdatel'stvo pp: 64.

13. Blinov VA (2002) Medicinal plants in diabetes mellitus. Moscow: OAO Izdatel'stvo pp: 64.

14. Bubenchikova VN, Bubenchikov AA, Filippenko NG (2000) Family Medicine: Herbal medicine at your home. Moscow: «RIPOL KLASSIK» Kursk: GUIPP pp: 320.
15. Chikov PP (1997) Medicinal plants-the path to health. Moscow: Nauchno-izdatel'skii tsentr «Inzhener» pp: 489.

16. Dannikov NI (2000) Your herbalist. Moscow: «Ripol Klassi» pp: 543.

17. Daryanina PA, Daryanin PA (1994) Healing gift of plants. Novosibirsk: Novosibirskoe knizhnoe izdatel'stvo pp: 128.

18. Dremova NB, Bubenchikova VN, Drozdova IL, Dzharu M (2003) Modern medicines and herbal medicine in treatment of diabetes mellitus: a teaching aid. Kursk: KGMU pp: 64.

19. Gomenyuk GA, Danilenko VP, Gomenyuk IG, Danilenko IV (2001) The practical application of medicinal plant collections: Handbook. Kiev: APK pp: 432.

20. Goncharova TA (2001) Encyclopedia of Medicinal Plants (3rdedn) Moscow: Izd. Dom MSP 1: 559.

21. Gorbunova TA (1994) Treatment with plants: Formulation Handbook. Moscow: Argumenty i fakty pp: 304.

22. Gubanov IA, Kiseleva KV, Novikov VP (1993) Wild useful plants. 2-nd ed. / Moscow: MGU pp: 300.

23. Gubergrits AY, Solomchenko NI (1990) Medicinal Plants of Donbass (5thedn) Donetsk pp: 280.

24. Ivanov VI (1992) Drugs in folk medicine. Moscow: Voenizdat pp: 448

25. Kiseleva TL, Smirnova YA (2009) Medicinal plants in the world medical practice: state regulation of the range and quality. Moscow: Publishing House of the Professional Association of Naturotherapists pp: 295.

26. Kiseleva TL, Smirnova YA, Blinkov IL, Dronova MA, Tsvetayeva YV (2010) A Brief Encyclopedia of Modern Phytotherapy with Homeopathy Fundamentals: a Reference Books for Practitioners. In: Kiseleva TL. Moscow: Publishing House of the Professional Association of Naturotherapists pp: 592.

27. Kolesova VG, Marchenko VA, Syrovezhko NV (1998) Traditional (folk) medicine in the lens of science. Saint-Petersburg: SPKhFA pp: 261.

28. Konstantinov AA (1995) East Family Medicine: A Collection of useful tips and recipes of traditional medicine. Khabarovsk: Izd-vo "RIOTIP» pp: 240.

29. Korchan VI, Kulemza KB (1993) Secrets of Traditional Medicine. Moscow: Talisman pp: 240.

30. Kortikov VN, Kortikov AV (1996) Directory of Traditional Medicine. Rostov-na-Donu: «Feniks» pp: 672.

31. Kostinskaya N.E. Children's green pharmacy. Minsk: Universitetskae; Mezhdunarodnyi tsentr kul'tury knigi, 1999. 279 p.

32. Krylov AA, Marchenko VA (2000) Guide to Herbal Medicine. SaintPetersburg.: Piter pp: 416.

33. Krylov AA, Marchenko VA, Maksyutina NP, Mamchur FI (1991) Phytotherapy in treatment of diseases of internal organs. Kiev: Izdatel'stvo «Zdorov'ya» pp: 240.

34. Kurkin VA (2009) Basics of phytotherapy. Samara: OOO «Ofort»; GOU VPO «samgmu Roszdrava» pp: 963.

35. Ladynina EA, Morozova RP, Fitoterapiya L (1987) Meditsina pp: 208.

36. Ladynina EA, Travnik D (1993) Moscow: Mosgorpechat' pp: 288.

37. Ladynina EA, Mudrost' trav (2003) Wisdom herbs. Herbal Medicine and Homeopathy. Moscow: OOO «aif Print» pp: 364.

38. Lavrenova GV (2010) Home herbalist. Moscow: ZAO «OLMA Media Grupp» pp: 640.

39. Makhov A.A. Green Pharmacy: Medicinal Plants of the Krasnoyarsk Territory. 2nd ed. Krasnoyarsk: Kn. Izd-vo, 1980. 320 p.

40. Makhlayuk VP (1992) Medicinal plants in folk medicine. Moscow: Niva Rossii pp:477.

41. Matkovskaya AN, Trumpe TE, Sokolov PY (1988) Phytotherapy in treatment of diabetes mellitus: Lecture. TsOLIUV pp: 22.

42. Maznev NI (1996) Traditional methods of treating of diseases. (3rdedn) Moscow: AO «Stoletie» pp: 560.

43. Maznev NI (1999) Medicinal plants: reference book. Moscow: «Martin» pp: 479. 
44. Lazebnyi A (1999)Medicinal plants and their application. L'vov: SvyatoUspenskaya Pochaevskaya Lavra pp: 432.

45. Minaeva VG (1991) Medicinal herbs of Siberia. 5th ed. Novosibirsk: Nauka Sib Otdelenie pp: 431.

46. Minedzhyan GZ (1991) Collection of folk medicine and non-traditional methods of treatment. Moscow: «TEKhNOEKOS» pp: 491.

47. Belyaev NV (1999)Modern Encyclopedia of herbs. Minsk: Sovremennyi literator pp: $928 \mathrm{p}$.

48. Nesterovskaya AY, Rendyuk TD, Speshilov LY, Speshilova NY, Lokotkova LL (1997) The Encyclopedia of herbal teas. Moscow: KRON-PRESS pp: 592.

49. Nikolaichuk LV (1989) Hypoglycemic plants. Minsk: Uradzhai pp: 191.

50. Nikolaichuk LV (1997) Diabetes treatment using plants. Minsk: Sovremennoe slovo pp: 256.

51. Nikolaichuk LV (2002) The healing power of plants. Recipes treatment and supply. Minsk: $\mathrm{OOO}$ «Krasiko-Prinat» pp: 352.

52. Nikolaichuk LV, Kozyuk EP (2005) Treatment with chamomile and calendula (2ndedn) Minsk: OOO «Sovremennoe slovo» pp: 192.

53. Nikul'tseva TM (1993) Herbal medicine: Collection of People's unconventional methods of treatment. Moscow: Pavlin pp: 384.

54. Nosal' MA, Nosal' IM (1959) Medicinal plants and their use in people. In: Drobot'ko VG (editor) Kiev: Gosudarstvennoe meditsinskoe izdatel'stvo USSR pp: 255

55. Orlova EA (2001) Herbal medicine: Medical mysteries of nature Moscow: TERRA- Knizhnyi klub pp: 560.

56. Pastushenkov LV, Pastushenkov AL, Pastushenkov VL (1998) Medicinal Herbs: The use of traditional medicine and life Spb: DEAN pp: 384.

57. Preobrazhenskii V (2001) Modern Encyclopedia of medicinal plants Rostov-on-Don: OOO «Izdatel'stvo BARO-PRESS» pp: 592.

58. Putyrskii I, Prokhorov V (2000) The universal encyclopedia of medicinal plants. Mn. Knizhnyi dom; Moscow: Makhaon pp: 656.

59. Reshetnyak VV, Tsigura IV, Travnik Kh (1992) Prapor pp: 463.

60. Reshetnyak VV, Tsigura IV, Reshetnyak EV, Travnik K (2000) APK pp: 496.

61. Sedova AB, Zorina EV (2006) Medicinal plants in the treatment of diabetes. In: Oleshko GI, Perm': GOU VPO «PGFA Roszdrava» pp: 227.

62. Sidorov PI (1992) Doctor book: Traditional recipes. Moscow: Voenizdat pp: 110.

63. Sklyarevskii LY, Gubanov IA (1989) Medicinal plants in everyday life. (3rd edn) Moscow: Rosagropromizdat pp: 272.

64. Sokolov PY (2000) Phytotherapy and phytopharmacology: A Guide for Physicians. Moscow: Meditsinskoe informatsionnoe agentstvo pp: 976.

65. Sokolov PY, Zamotaev IP (1988) Handbook of Medicinal Plants Phytotherapy. (2ndedn). Moscow: Meditsina pp: 464.

66. Stoyanovskii DN (2003) How to cure the 200 most common diseases Moscow: OOO «Izdatel'stvo AST»; Donetsk: «Stalker» pp: 296.

67. Svyashchennik AZ (2008) God's healer: a handbook of medicinal herbs and plants. -Moscow: OOO «OBRAZ» pp: 572.

68. Tarasenko VP, Ipat'ev VA, Zorin VP, Tarasenko IA (1999) Forest Phytotherapy. Minsk: Uradzhai pp: 303.

69. Treskunov VK, Treskunov KA, Treskunova OK (1992) Fitoterapiya. Moscow: Firma «RIPI» pp: 145.

70. Turishchev PN (2000) Rational phytotherapy. Moscow: Informpechat pp: 240.

71. Tovstukha EP (1994) Ukrainian Folk Medicine: 1000 unique author's recipes. Kiev: Vidavnitstvo «Ros'» pp: 350.

72. Uzhegov GN (2001) The Golden Book of Traditional Medicine. Moscow: Veche pp: 592.

73. Zakharov YA (2006) Diabetes: Herbs and insulin. Moscow: Kolos pp: 160.
74. Zobern V (2008) Orthodox healer. Moscow: Russkaya missiya pp: 475

75. Zubitskaya NP, Nikolaichuk LV (2001) Child treats nature: Medicines from plants. Plants in the diet. Plants in nutrition. Healing baptistery. Kiev: Interpress LTD: 287.

76. Tutelyan VA, Kiseleva TL, Kochetkova AA, Smirnova EA, Kiseleva MA, et al. (2016) Promising Sources of Phytonutrients for Special Foods with a Modified Carbohydrate Profile: Traditional Medicine Experience. Voprosy pitaniya 85: 46-60.

77. Fraiture A (2014) Toxicity to livestock and medicinal uses of Galega officinalis (Leguminosae) and galegine. Ann Méd Vét; 158: 99-108.

78. Keeler RF, Johnson AE, Stuart LD, Evans JO (1986) Toxicosis from and possible adaptation to Galega officinalis in sheep and the relationship to Verbesina encelioides toxicosis. Vet hum Toxicol 28: 309-315.

79. Keeler RF, Baker DC, Evans JO (1988) Individual animal susceptibility and its relationship to induced adaptation or tolerance in sheep to Galega officinalis L. Vet Hum Toxicol 30: 420-423.

80. Faliu L, Puyt JD, Jean-Blain C (1985) Intoxication végétale : galega officinal. Point vét 17: 453-455

81. Köhler H (1969) Die Prüfung von Galega-Arten auf ihren Gehalt an Giftstoffen mit Hilfe biologischer Methoden, I - Die Giftigkeit der Geißraute (Galega officinalis L.) für Warmblütter. Biol Zentralbl 88: 165-177.

82. Kiseleva MA, Kiseleva TL, Kochetkova AA, Tutelyan VA (2017) Evaluation of Prognostic Allergological Risks Related to Inclusion of Plant Extracts into Drugs and Special Foods for Those Suffering from Type II Diabetes Mellitus. Traditional Medicine 2: 40-19.

83. Watson EM (1928) Some Observations on the Effect of Blueberry Leaf Extract in Diabetes Mellitus. Can Med Assoc J 19:166-171.

84. Martineau L, Couture A, Spoor D, Benhaddou-Andaloussi A, Harris C, Meddah B, et al (2006) Anti-diabetic properties of the Canadian lowbush blueberry Vaccinium angustifolium Ait. Phytomedicine 13: 612-623.

85. Grace M, Ribnicky D, Kuhn P, Poulev A, Logendra S, et al. (2009) Hypoglycemic activity of a novel anthocyanin-rich formulation from lowbush blueberry, Vaccinium angustifolium Aiton. Phytomedicine 16: 406-415.

86. Ehlenfeldt MK, Prior RL (2001) Oxygen Radical Absorbance Capacity (ORAC) and Phenolic and Anthocyanin Concentrations in Fruit and Leaf Tissues of Highbush Blueberry. J Agric Food Chem; 49: 2222-2227.

87. Jeong H, Jo Y, Jeong J, Kim H, Kim M, et al. (2013) Blueberry ( Vaccinium virgatum ) Leaf Extracts Protect Against A $\beta$-Induced Cytotoxicity and Cognitive Impairment. J Med Food 16: 968-976.

88. Lee IC, Kim DY, Choi BY (2014) Antioxidative Activity of Blueberry Leaf Extract Prevents High-fat Diet-induced Obesity in C57BL/6 Mice. J Cancer Prev19: 209-215.

89. Nagao K, Higa K, ShirouchI B, Nomura S, Inoue N, et al. (2008) Effect of Vaccinium ashei reade Leaves on Lipid Metabolism in Otsuka LongEvans Tokushima Fatty Rats. Biosci Biotechnol Biochem 72: 1619-1622.

90. Inoue N, Nagao K, Nomura S, Shirouchi B, Inafuku M, et al. (2011) Effect of Vaccinium ashei reade Leaf Extracts on Lipid Metabolism in Obese OLETF Rats. Biosci Biotechnol Biochem; 7: 2304-2308.

91. Yuji K, Sakaida H, Kai T, Fukuda N, Yukizaki C, et al. (2013) Effect of dietary blueberry (Vaccinium ashei Reade) leaves on serum and hepatic lipid levels in rats. J Oleo Sci 62: 89-96.

92. Shipelin VA, Sidorova YS (2017) A Study on Anti-Diabetic Activity of Bilberry Leaves in a Zucker Rat Type II Diabetes Mellitus Model. Contemporary Issues of Nutritiology, Biotechnology, and Food Safety 1: $146-150$.

93. Sidorova YS, Shipelin VA, Mazo VA, Zorin SN, Petrov NA, et al. (2017) Hypoglycemic and hypolipidemic effect of Vaccinium myrtillus L. leaf and Phaseolus vulgaris L. seed coat extracts in diabetic rats. Nutrition 41: 107-112. 